Atmos. Chem. Phys., 13, 9195-9210, 2013

www.atmos-chem-phys.net/13/9195/2013/

doi:10.5194/acp-13-9195-2013

(c) Author(s) 2013. CC Attribution 3.0 License.

\title{
Absorption properties of Mediterranean aerosols obtained from multi-year ground-based remote sensing observations
}

\author{
M. Mallet ${ }^{1}$, O. Dubovik ${ }^{2}$, P. Nabat ${ }^{3}$, F. Dulac ${ }^{4}$, R. Kahn ${ }^{5}$, J. Sciare ${ }^{4}$, D. Paronis ${ }^{6}$, and J. F. Léon ${ }^{1}$ \\ ${ }^{1}$ Laboratoire d'Aérologie, UMR5560, Toulouse, France \\ ${ }^{2}$ Laboratoire d'Optique Atmosphérique, Lille, France \\ ${ }^{3}$ CNRM-GAME, Météo-France, Toulouse, France \\ ${ }^{4}$ Laboratoire des Sciences du Climat et de l'Environnement (IPSL/LSCE), CEA-CNRS-USVQ, Gif-sur-Yvette, France \\ ${ }^{5}$ NASA Goddard Space Flight Center, Maryland, USA \\ ${ }^{6}$ National Observatory of Athens, Institute for Astronomy, Astrophysics, Space Applications and Remote Sensing, Athens, \\ Greece
}

Correspondence to: M. Mallet (marc.mallet@aero.obs-mip.fr)

Received: 12 February 2013 - Published in Atmos. Chem. Phys. Discuss.: 8 April 2013

Revised: 22 July 2013 - Accepted: 5 August 2013 - Published: 16 September 2013

\begin{abstract}
Aerosol absorption properties are of high importance to assess aerosol impact on regional climate. This study presents an analysis of aerosol absorption products obtained over the Mediterranean basin or land stations in the region from multi-year ground-based AERONET observations with a focus on the Absorbing Aerosol Optical Depth (AAOD), Single Scattering Albedo (SSA) and their spectral dependence. The AAOD and Absorption Angström Exponent (AAE) dataset is composed of daily averaged AERONET level 2 data from a total of 22 Mediterranean stations having long time series, mainly under the influence of urbanindustrial aerosols and/or soil dust. This dataset covers the 17-yr period 1996-2012 with most data being from 20032011 ( $\sim 89 \%$ of level-2 AAOD data). Since AERONET level-2 absorption products require a high aerosol load (AOD at $440 \mathrm{~nm}>0.4$ ), which is most often related to the presence of desert dust, we also consider level-1.5 SSA data, despite their higher uncertainty, and filter out data with an Angström exponent $<1.0$ in order to study absorption by carbonaceous aerosols. The SSA dataset includes AERONET level-2 products. Sun-photometer observations show that values of AAOD at $440 \mathrm{~nm}$ vary between $0.024 \pm 0.01$ (resp. $0.040 \pm 0.01)$ and $0.050 \pm 0.01(0.055 \pm 0.01)$ for urban (dusty) sites. Analysis shows that the Mediterranean urbanindustrial aerosols appear "moderately" absorbing with values of SSA close to $\sim 0.94-0.95 \pm 0.04$ (at $440 \mathrm{~nm}$ ) in most cases except over the large cities of Rome and Athens, where
\end{abstract}

aerosol appears more absorbing (SSA $\sim 0.89-0.90 \pm 0.04$ ). The aerosol Absorption Angström Exponent (AAE, estimated using 440 and $870 \mathrm{~nm}$ ) is found to be larger than 1 for most sites over the Mediterranean, a manifestation of mineral dust (iron) and/or brown carbon producing the observed absorption. AERONET level-2 sun-photometer data indicate a possible East-West gradient, with higher values over the eastern basin $\left(\mathrm{AAE}_{\text {East }}=1.39 / \mathrm{AAE}_{\text {West }}=1.33\right)$. The NorthSouth AAE gradient is more pronounced, especially over the western basin. Our additional analysis of AERONET level1.5 data also shows that organic absorbing aerosols significantly affect some Mediterranean sites. These results indicate that current climate models treating organics as nonabsorbing over the Mediterranean certainly underestimate the warming effect due to carbonaceous aerosols.

\section{Introduction}

Numerous studies have identified the Mediterranean basin as one of the most prominent "Hot-Spots" in projected climate change assessments (Giorgi, 2006; Giorgi and Lionello, 2008). General Circulation Model (GCM) or Regional Climate Model (RCM) climate simulations have demonstrated that the Mediterranean is characterized by its vulnerability to changes in the water cycle and predict a substantial precipitation decrease and warming, especially during the summer 
season. By the end of 21st century, the average prediction of the models suggests a significant loss of freshwater over the Mediterranean basin: -40\% for the period 2070-2090 compared to 1950-1999 (Sanchez-Gomez et al., 2009). Climate simulations underline that the drying of the Mediterranean basin is associated with increasing anticyclonic circulation over the region, which causes a northward shift of the midlatitude storm track (Giorgi and Lionello, 2008).

Until now, most global and regional future climate simulations have only investigated the impact of global warming on the Mediterranean climate without clearly considering the influence of "Mediterranean aerosols" (pollution particles, smoke and mineral dust) that can significantly modify the radiation budget (Markowicz et al., 2002; Formenti et al., 2002b; Mallet et al., 2006; Roger et al., 2006). Specifically, atmospheric aerosols decrease the amount of shortwave (SW) radiation reaching the sea and continental surfaces. The column amount of atmospheric aerosol, quantified by the Aerosol Optical Depth (AOD), is one of the main factors causing this decrease. This aerosol-induced perturbation of the surface radiation budget can impact the Sea Surface Temperature (SST) (Foltz and McPhaden, 2008; Yue et al., 2011) and surface moisture exchanges by modifying latent heat fluxes (Ramanathan et al., 2001a).

In addition, due to their optical properties and especially their ability to absorb solar radiation, aerosols can trap SW radiation within the atmospheric layer where they reside. This additional absorption contributes to the direct heating of the atmosphere and causes changes in the atmospheric heating rate profiles, dynamical processes and more generally, the hydrological cycle (Solmon et al., 2008; Lau et al., 2009; Mallet et al., 2009). For example, Solmon et al. (2008) simulate that a change in dust absorbing properties could modify precipitation over Western Africa. Ramanathan et al. (2001b) also conclude that heating caused by carbonaceous absorbing aerosols exported from India reduces the low cloud fraction over the Indian Ocean during the dry monsoon season. Therefore, a rigorous quantification of the effect of aerosols on the Mediterranean radiation budget and climate is required, including estimates of both the atmospheric aerosol load and its ability to absorb radiation.

Numerous studies of aerosol properties over the Mediterranean have documented AOD for pollution particles, smoke and dust aerosols using in-situ observations (Horvath et al., 2002; Formenti et al., 2002a; Gerasopoulos et al., 2003; Kubilay et al., 2003; Meloni et al., 2004, 2006; Fotiadi et al., 2006; Pace et al., 2006; Roger et al., 2006; Mallet et al., 2006; Tafuro et al., 2007; Saha et al., 2008). In brief, these studies report AOD values in the range 0.1-0.5, 0.3-1.8 and $0.3-0.8$ in the spectral range of 440 to $550 \mathrm{~nm}$ for pollution, dust and smoke particles, respectively. In addition to analyses of local sun-photometer observations, several studies have used long time series of satellite-derived AOD at regional scales from Meteosat (Moulin et al., 1998), SeaWiFs (Antoine and Nobileau, 2006), the MODerate resolution Imag- ing Spectroradiometer (MODIS) (Barnaba and Gobbi, 2004; Papadimas et al., 2008, 2009; Nabat et al., 2012), the combination of MODIS and TOMS (Hatzianastassiou et al., 2009), MSG/SEVIRI (Lionello et al., 2012), or even all products (Nabat et al., 2013).

In contrast to the considerable scientific literature related to AOD distribution, aerosol absorbing properties over the Mediterranean have received much less attention, and are poorly documented, in spite of their great importance for direct radiative forcing and overall regional climate. To the best of our knowledge, the only long term in-situ observations of absorbing aerosols available in the Mediterranean background atmosphere are those reported from Crete Island in the eastern Mediterranean by Sciare et al. (2008), highlighting the major role of long-range transported biomass burning aerosols on Black Carbon (BC) concentration levels. Consequently, long-term observations of absorption in the atmospheric column, and specifically an analysis of the role played by dust aerosols, are still missing. This motivates the present work; its main objective is to characterise aerosol absorption over the Mediterranean region using available surface remote-sensing data. We focus our study on (i) the aerosol absorption optical depth (AAOD), which is the fraction of AOD due to absorption only, (ii) the aerosol single scattering albedo (SSA), which is the ratio of aerosol scattering to total extinction (i.e. scattering + absorption), and (iii) the spectral dependence of these optical parameters, calculated in terms of Angström Exponent (AE) or Absorption Angström Exponent (AAE) in the case of optical depth or absorption optical depth, respectively:

$$
\begin{aligned}
\mathrm{AAE} & =\log \left(\mathrm{AOD}_{\lambda 1} / \mathrm{AOD}_{\lambda 2}\right) / \log \left(\lambda_{2} / \lambda_{1}\right) \text { and } \mathrm{AAE} \\
& =\log \left(\mathrm{AAOD}_{\lambda 1} / \mathrm{AAOD}_{\lambda 2}\right) / \log \left(\lambda_{2} / \lambda_{1}\right)
\end{aligned}
$$

Subsequent to the data description (ground-based dataset used in our work) in Sect. 2, the results are presented and discussed in two main parts. First (Sects. 3.1-3.2), we report AAOD and AAE AERONET level-2 and 1.5 multi-year observations for different Mediterranean sites. AERONET SSA is analysed in Sect. 3.3.

\section{Remote sensing ground-based AERONET observations}

AERONET (Aerosol Robotic Network; http://aeronet.gsfc. nasa.gov/) is a federated network of ground-based sunphotometers and the associated data inversion and archive system, that routinely performs direct sun observations every $15 \mathrm{mn}$, and both almucantar and principal plane sky radiance measurements, and retrieves and distributes global aerosol columnar properties (Holben et al., 1998). Along with AOD observations, the AERONET aerosol retrieval algorithm (Dubovik and King, 2000) delivers the complete set of column-effective aerosol microphysical parameters, including volume size distribution, refractive index at four 


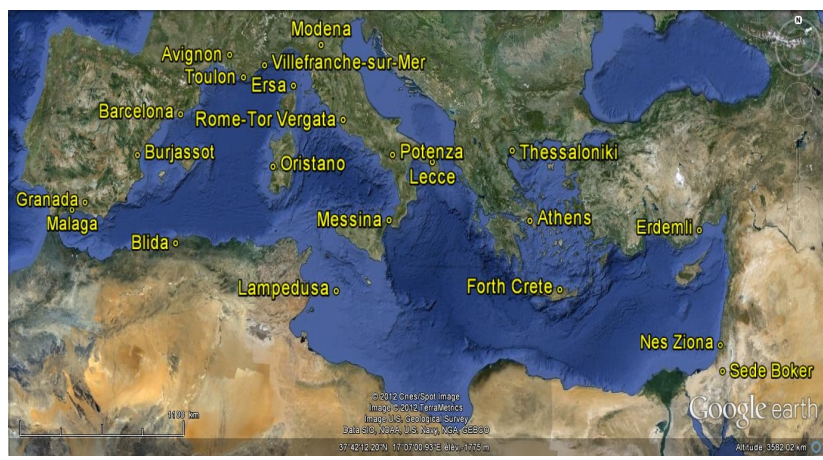

Fig. 1. Location of the 22 Mediterranean AERONET sites with long time series used in this work. Northernmost (resp. southernmost) sites are found in the western (eastern) basin.

wavelengths $(440,670,870$ and $1020 \mathrm{~nm})$ and fraction of spherical particles (Dubovik et al., 2006, also see description in Dubovik et al., 2011). In addition, using these microphysical parameters, the algorithm provides other columneffective aerosol optical properties of interest to the scientific community, such as wavelength dependent SSA, phase function, and asymmetry parameter, as well as integral parameters of bi-modal particle size distributions (concentration, mode radii and variances) (Dubovik et al., 2002). In the present study, the analysis is mostly focused on AAOD and SSA for AERONET level 2.0, cloud-screened and qualityassured AOD (Smirnov et al., 2000) and level 2.0 inversion products (Dubovik et al., 2002). The accuracy of AERONET retrievals is evaluated and discussed by Dubovik et al. (2000, 2002): the uncertainty of retrieved AAOD is estimated at the level of \pm 0.01 at wavelengths $440 \mathrm{~nm}$ and greater, whereas SSA uncertainty is estimated to be \pm 0.03 for AOD $(440 \mathrm{~nm})$ $>0.2$ for water soluble aerosols and for AOD $(440 \mathrm{~nm})>0.5$ (zenith angle larger than 50 degrees) for desert dust and biomass burning particles. Finally, for AOD $(440 \mathrm{~nm})<0.2$, the SSA accuracy is $\pm 0.05-0.07$ (Dubovik et al., 2000, 2002). The AERONET's Version 2.0 quality assured aerosol products were used. The criteria used for Version 2.0 quality assurance are described in details by Holben et al. (2006).

The 22 AERONET Mediterranean sites considered in our study are selected based on both their location (within or close to the basin) and their long-term operation ( $>2.5 \mathrm{yr}$ ). They are mapped in Fig. 1 and listed in Table 1 along with information regarding the location, period of observation and a brief description of each site. The significant number of AERONET sites available over the Mediterranean and their distribution allows us to investigate aerosol characteristics under diverse conditions: over remote, anthropogenicpolluted and dusty locations. Figure 2 plots averaged level-2 $\mathrm{AE}$ and AOD of the different stations. The 4 stations of Thessaloniki, Erdemli, Nes Ziona and Modena show a high AOD range $(0.28-0.32)$ whereas all other have an average $<0.23$. The high AE $(\sim 1.55)$ at Modena and Thessaloniki indicate

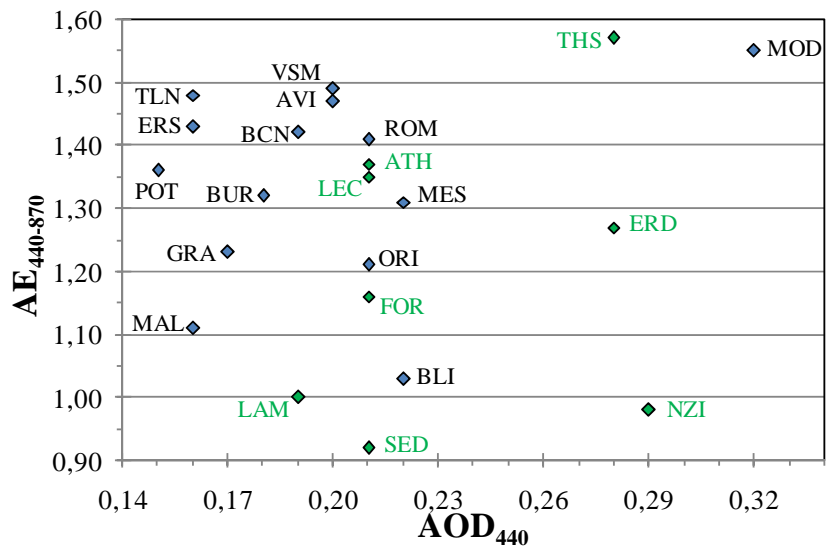

Fig. 2. Average AERONET level 2 aerosol Angström Exponent and optical depth of the 22 selected stations. The 8 stations in green are relevant of the eastern Basin (see Table 1 for the station codes).

urban pollution controlled by submicron particles. On the opposite, the low average AE value $(<1.0)$ at Nes Ziona reveals the major influence of large particles, likely soil dust and possibly sea salt. Lampedusa, Blida and Sede Boker also show a low $\mathrm{AE}(\sim 1)$, characterising a major influence of large particles in conditions of lower AOD $(\sim 0.2)$. With intermediate $\mathrm{AE}$ values in the range 1.11-1.27 the stations of Malaga, Granada, Oristano, Forth Crete and Erdemli correspond to relatively southern stations (Fig. 1) where the influence of desert dust from the south is still very significant. Larger AE values in the range 1.31-1.37 correspond to stations in a latitude band 38-40.6 ${ }^{\circ} \mathrm{N}$ (Burjassot, Potenza, Lecce, Messina and Athens) where the impact of dust is less visible but still significant. The rest of the stations has an $\mathrm{AE}$ in the range 1.41-1.49 and is composed of more northern stations in the western basin (Barcelona, Rome, Avignon, Ersa, Toulon, and Villefranche). As a result, a very significant trend is found between $\mathrm{AE}$ and station latitude, whereas AOD rather correlates with the station longitude (Fig. 3).

Figure 4 provides the temporal distribution of the number of days per month with AERONET level-2 absorption products available at each site considered. Numbers are most often $<10$ and this number is rarely exceeded at other seasons than summer. The period covered spans from 1996 to 2012, but a single station of Sede Boker provides data before 2000. Figure 5 further plots some statistics. Twelve stations have at least 110 days of level-2 absorption products. The number ranges between 18 and 365 days (at Ersa and Erdemli, resp.) and the maximum number of days is always found in the summer season which is known to be the maximum dust season in the western and central Mediterranean (Moulin et al., 1998). 88.8\% of data are from the period 2003-2011. As AERONET level-2 derivations correspond to a high aerosol load (AOD at $440 \mathrm{~nm}>0.4$ ) that is generally associated to dust events, we also consider level-1.5 inversion products in order to investigate the possible role of smoke 

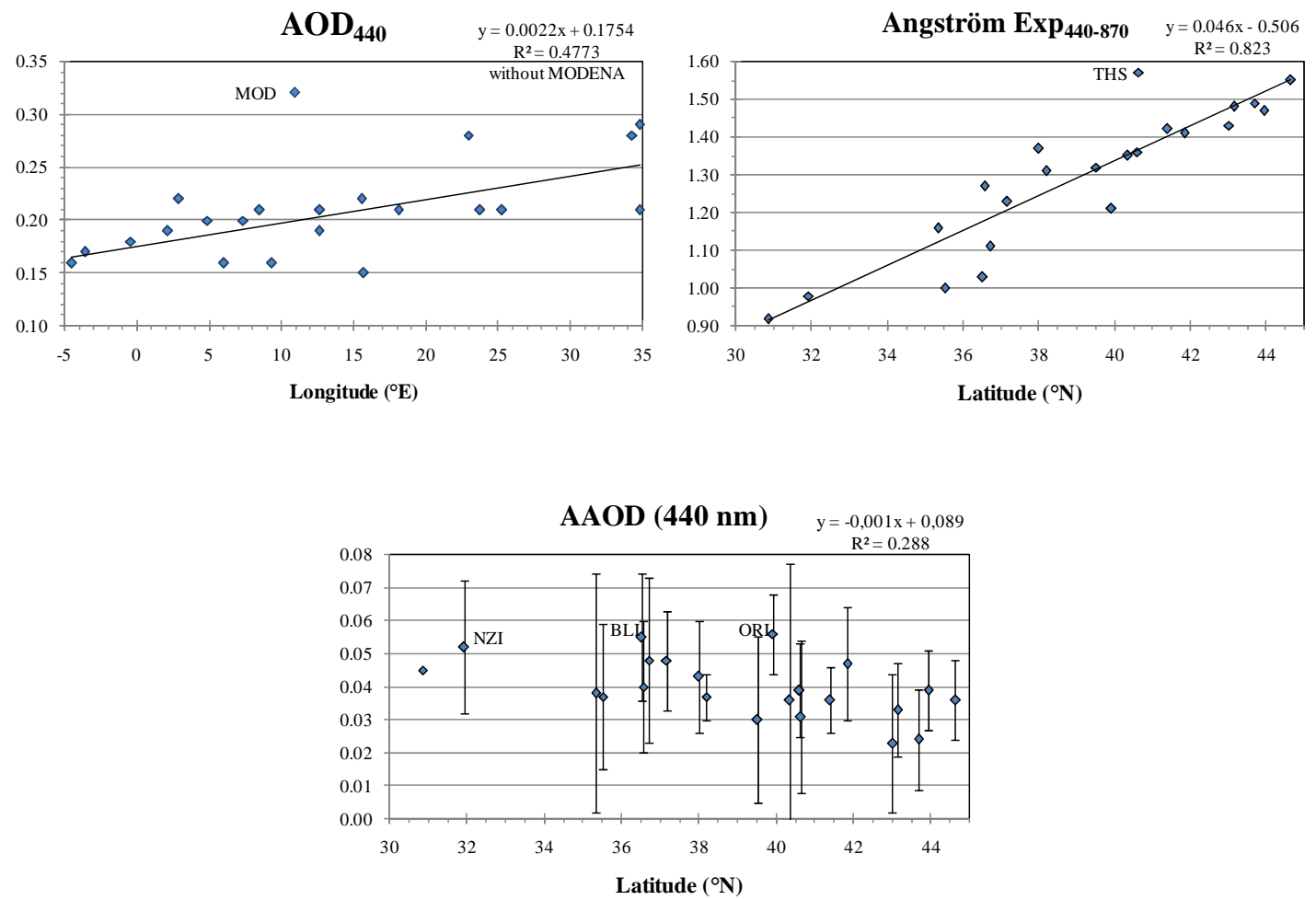

Fig. 3. AERONET level-2 average AOD as a function of station longitude and average AE and AAOD as a function of station latitude. Other data given in Table 2 are less or not significantly correlated with latitude or longitude with the exception of the real part of RI at 440 and $670 \mathrm{~nm}$ and the imaginary part of RI at $670 \mathrm{~nm}$ (not shown) that also correlate with latitude at the 0.01 level $\left(R^{2}>0.288\right.$ for 20 degrees of freedom).

aerosols on the absorption. We further limit the influence of dust events on the results by considering only level-1.5 data with an Angström Exponent >1.0. In that case, uncertainties on AAOD are estimated at about \pm 0.01 .

\section{Results and discussions}

\subsection{Aerosol absorption optical depth}

AAOD (Level 2) has been derived from AERONET observations at different wavelengths. We first analyse AAOD at $440 \mathrm{~nm}$ obtained at the 22 selected AERONET sites (Fig. 1, Table 2). Over urban-industrialized regions (Table 2), AAOD falls between $0.027 \pm 0.01$ and $0.05 \pm 0.01$ with the maximum observed at Rome (Table 2). In most cases, AAOD is around $0.03 \pm 0.01$ for other urban-polluted sites. Long-term analysis of the AERONET records at the Modena and Rome sites, having around $10 \mathrm{yr}$ of observations, does not reveal a clear AAOD trend excepted over Rome, where a decrease is observed $\left(-0.0005 \mathrm{yr}^{-1}\right)$ between 2001 and 2011 (Fig. 6). For periods of 3-5 yr between 2005 and 2008, Toulon and Thessaloniki display a possible decrease in AAOD (not shown), though the period of observations is too short to derive an AAOD trend with confidence.
Mediterranean urban AAODs obtained at $440 \mathrm{~nm}$ are in the same magnitude range as those observed over other urban sites such as Creteil/Paris $(\sim 0.015 \pm 0.01)$ or Mexico $(\sim 0.05 \pm 0.01)$, but are generally higher than AAOD obtained at GSFC (AAOD < 0.010 ) or over other sites along the US Atlantic coast (AAOD $\sim 0.01$ for the same wavelength) as reported by Russell et al. (2010). Compared to AAOD obtained during SAFARI (Southern Africa Regional Science Initiative) for smoke aerosols in southern Africa (AAOD $\sim 0.2$ at $440 \mathrm{~nm}$, see Russell et al., 2010) or in the JapanKorea region during ACE-Asia for mixed particles (AAOD of about 0.1 at $440 \mathrm{~nm}$ ), AAOD derived over the Mediterranean display lower values.

AERONET observations (Table 2) indicate that "dusty" sites (defined in Table 1) are logically characterized by larger mean AAOD (at $440 \mathrm{~nm}$ ) from $0.037 \pm 0.019$ at Lampedusa to $0.055 \pm 0.020$ at Blida and $0.056 \pm 0.041$ at Oristano with values in the range $0.045-0.052$ at Malaga, Granada, Nes Ziona and Sede Boker. Sites under desert dust influence seem to have experienced a decrease in AAOD (not shown) although conclusions made over such short time periods are highly uncertain (2003-2011 for Lampedusa, 2004-2009 for Blida). This observed decrease is consistent with the results obtained by Zhang and Reid (2010), who showed a negative trend in AOD of -0.022 per decade 


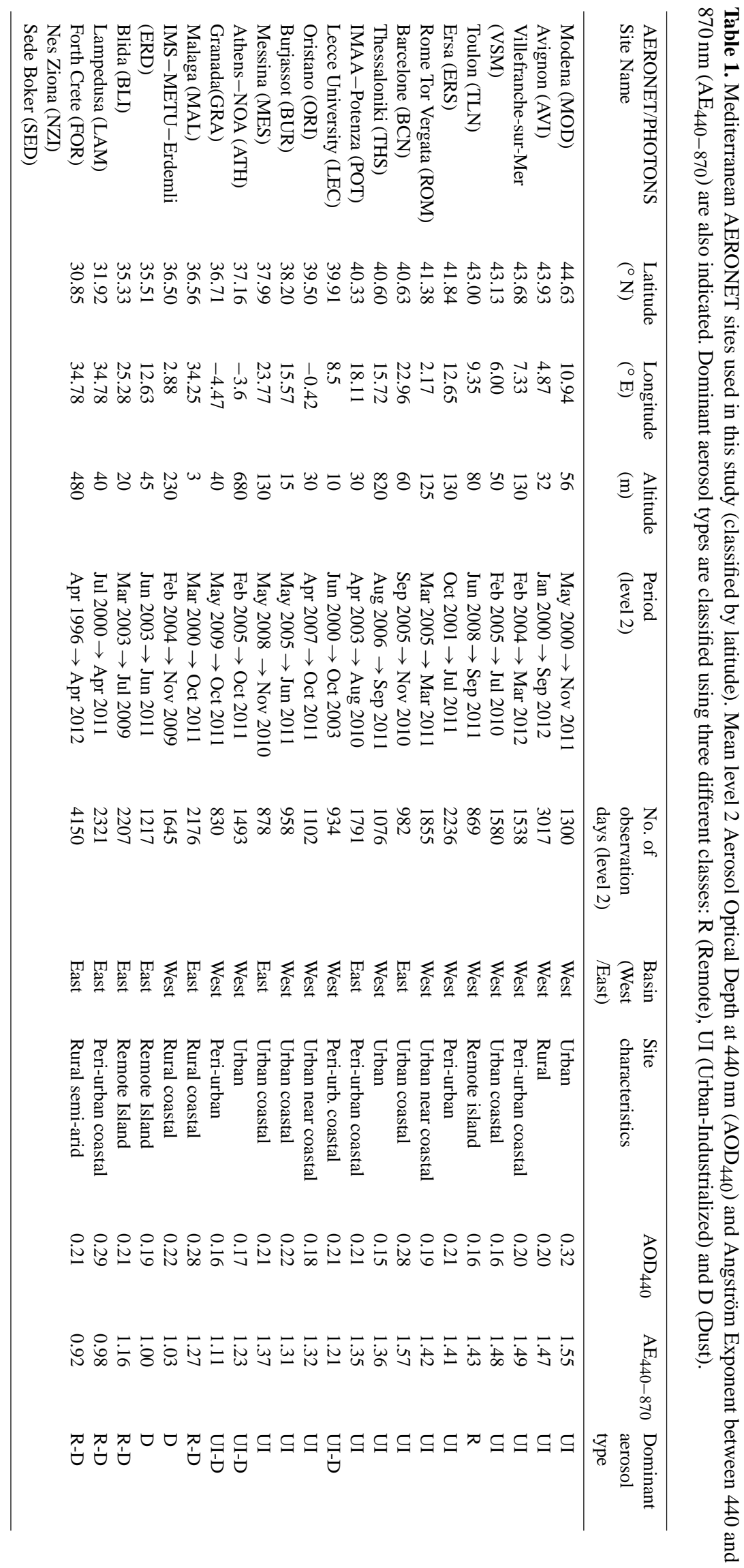



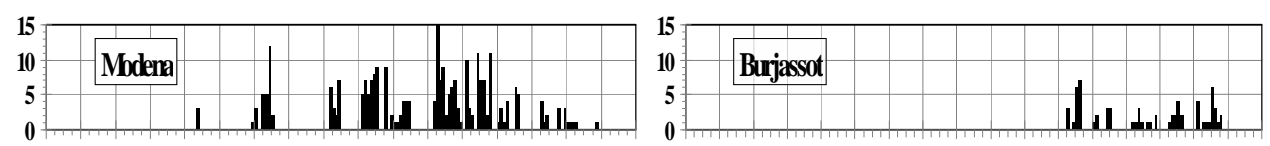

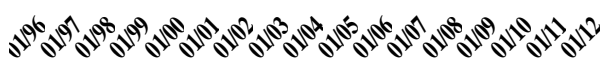
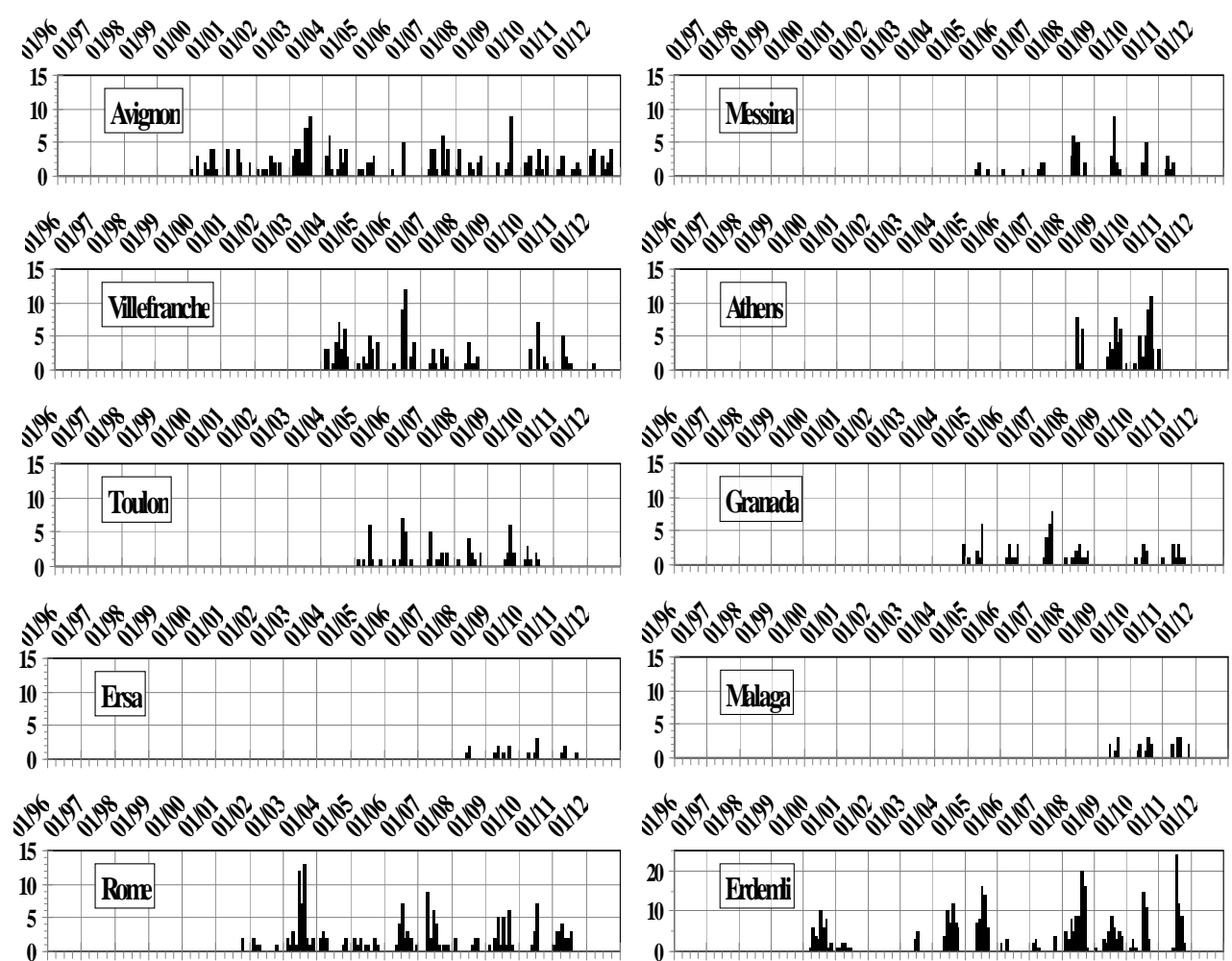

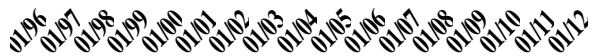

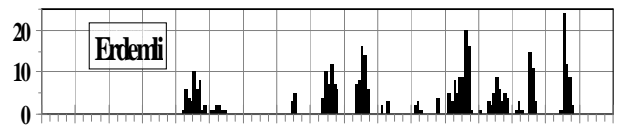

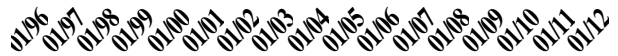
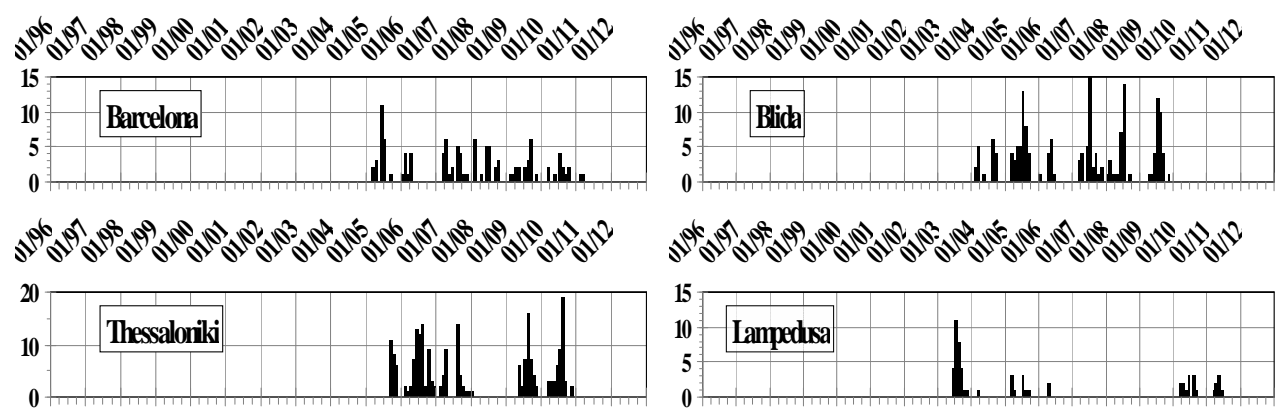

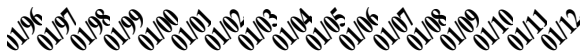

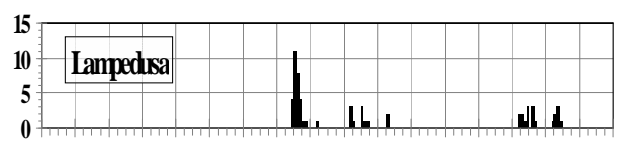

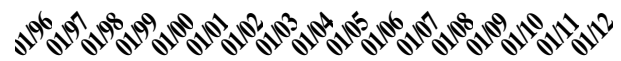

3.3.

Fig. 4. Number of days with available level-2 AAOD (at 440 or $441 \mathrm{~nm}$ ) data at every AERONET station and for each month from January 1996 to December 2012. Note that Thessaloniki and Erdemli have vertical scales different from other stations.

using the ten-year (2000-2009) Data Assimilation quality MISR/MODIS combined aerosol product over ocean. Other Mediterranean sites under the influence of dust aerosols display significant AAOD $\sim 0.050$. It should also be noted that similar values are found for AAOD observed over Puerto Rico during the PRIDE dust experiment (AAOD 0.05-0.06 at $440 \mathrm{~nm}$ ) and over dusty sites in Bahrain/Persian Gulf, Solar Village/Saudi Arabia or Cape Verde (Russell et al., 2010). A linear correlation between AAOD and latitude (Fig. 3) is found significant (at the 0.01 level).

\subsection{Aerosol Absorption Angström Exponent (AAE)}

\subsubsection{Aerosol Level-2 Product}

As reported by Russell et al. (2010), the spectral dependence of AAOD, as defined in Eq. (1), can provide useful information on the contribution different aerosol types make to the shortwave absorption:

$\mathrm{AAOD}=K \lambda^{-\mathrm{AAE}}$ 

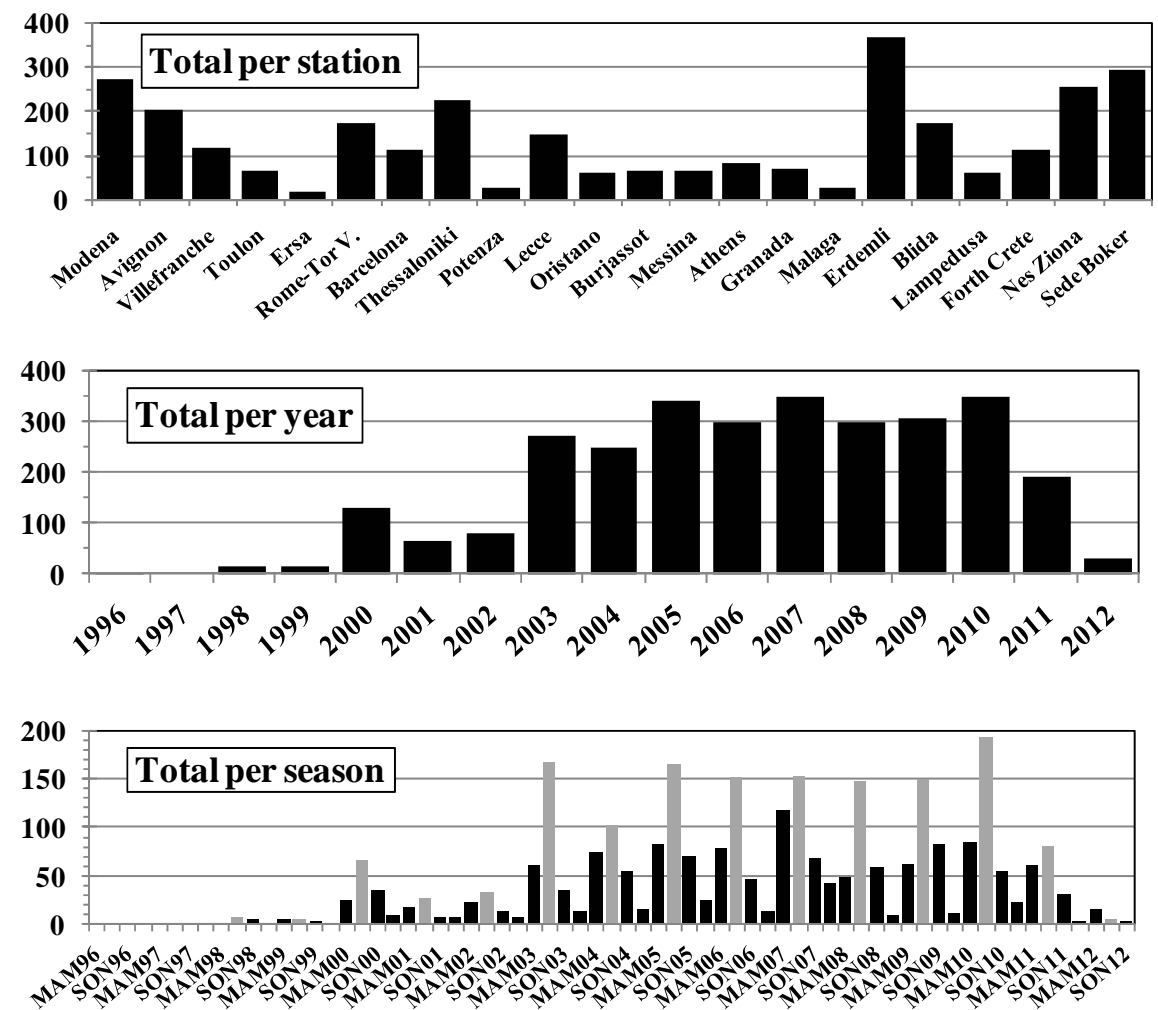

Fig. 5. Total number of days with available level-2 AAOD (at 440 or $441 \mathrm{~nm}$ ) data per station (top), and per year (middle) and per season (bottom, with summer seasons in grey) for stations altogether.

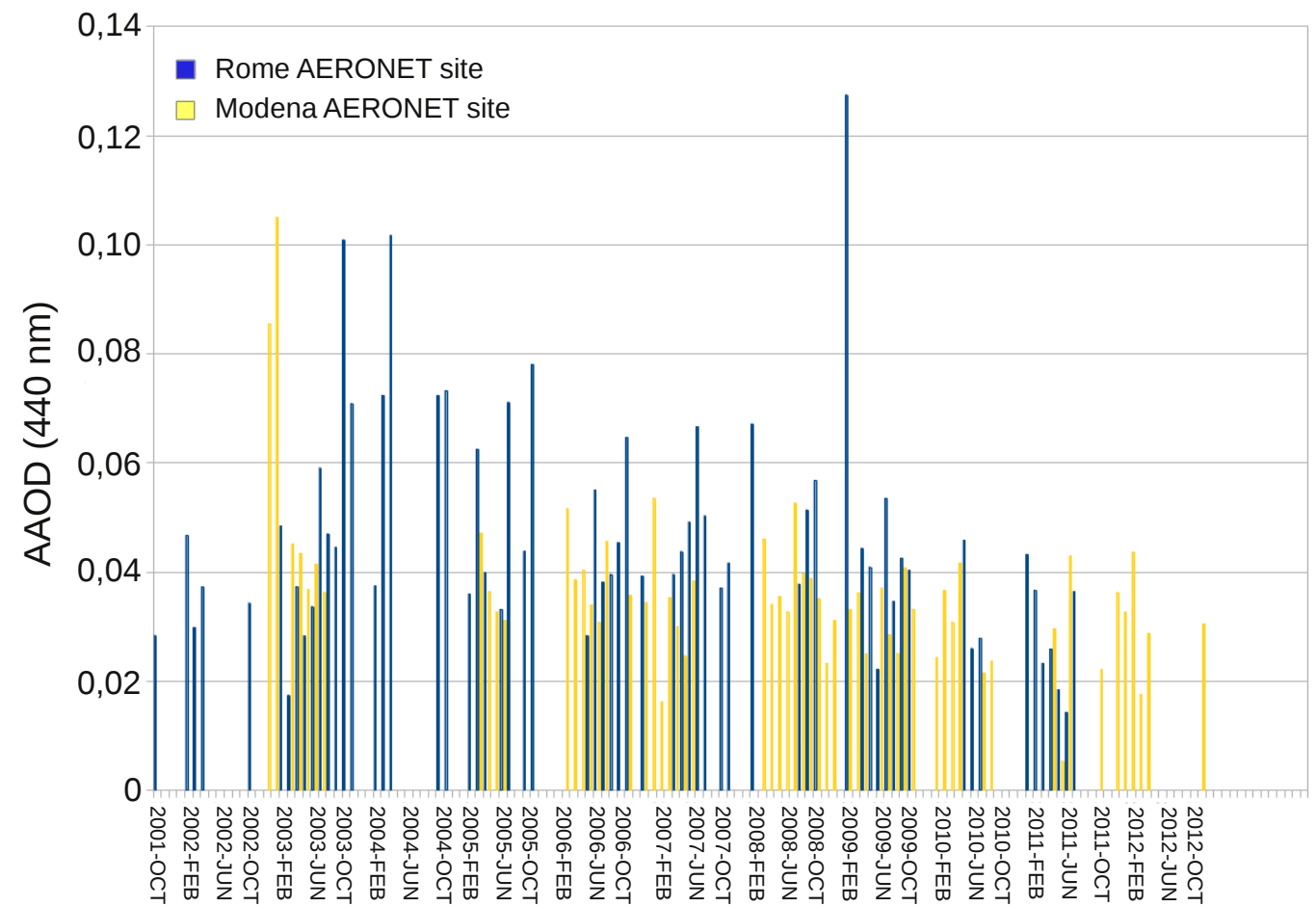

Fig. 6. Absorbing Aerosol Optical Depth, AAOD (Level 2, at $440 \mathrm{~nm}$ ) estimated at Rome and Modena for the 2001 to 2012 period. The uncertainty is about \pm 0.01 . 
Table 2. Level-2 averaged Aerosol Absorbing Optical Depth at $440 \mathrm{~nm}\left(\mathrm{AAOD}_{440}\right)$, Single Scattering Albedo at $440 \mathrm{~nm}\left(\mathrm{SSA}_{440}\right)$, Absorbing Angström Exponent estimated between 440 and $870 \mathrm{~nm}\left(\mathrm{AAE}_{440-870}\right)$, real and imaginary parts of aerosol Refractive Index (RI) at 440 and $670 \mathrm{~nm}$, and number of days with data over the time period reported in Table 1. Standard deviations (sigma) are also reported in parentheses for AOD, SSA and AAE.

\begin{tabular}{llllll}
\hline $\begin{array}{l}\text { AERONET/PHOTONS } \\
\text { Site }\end{array}$ & $\begin{array}{l}\mathrm{AAOD}_{440} \\
\text { (sigma) }\end{array}$ & $\begin{array}{l}\mathrm{SSA}_{440} \\
(\mathrm{sigma})\end{array}$ & $\begin{array}{l}\text { AAE } 440-870 \\
(\text { sigma })\end{array}$ & $\begin{array}{l}\text { Real Part of } \\
\text { RI at 440/670 nm }\end{array}$ & $\begin{array}{l}\text { Imaginary Part of RI } \\
\text { at 440/670 nm }(\cdot 10000)\end{array}$ \\
\hline Modena & $0.036(0.014)$ & $0.930(0.026)$ & $1.28(0.21)$ & $1.43 / 1.43$ & $97 / 86$ \\
Avignon & $0.039(0.012)$ & $0.918(0.023)$ & $1.24(0.37)$ & $1.42 / 1.43$ & $98 / 89$ \\
Villefranche-sur-Mer & $0.024(0.012)$ & $0.951(0.024)$ & $0.99(0.24)$ & $1.40 / 1.41$ & $55 / 58$ \\
Toulon & $0.033(0.015)$ & $0.929(0.034)$ & $1.20(0.32)$ & $1.40 / 1.42$ & $90 / 87$ \\
Ersa & $0.023(0.014)$ & $0.955(0.023)$ & $1.16(0.28)$ & $1.41 / 1.42$ & $55 / 56$ \\
Rome Tor Vergata & $0.047(0.021)$ & $0.904(0.042)$ & $1.50(0.43)$ & $1.43 / 1.44$ & $119 / 89$ \\
Barcelone & $0.036(0.017)$ & $0.929(0.027)$ & $1.19(0.48)$ & $1.42 / 1.42$ & $74 / 65$ \\
Thessaloniki & $0.031(0.010)$ & $0.937(0.020)$ & $1.33(0.19)$ & $1.38 / 1.40$ & $69 / 57$ \\
Potenza & $0.039(0.023)$ & $0.925(0.040)$ & $1.28(0.63)$ & $1.45 / 1.46$ & $73 / 75$ \\
Lecce University & $0.036(0.014)$ & $0.925(0.026)$ & $1.47(0.53)$ & $1.44 / 1.45$ & $76 / 64$ \\
Oristano & $0.056(0.041)$ & $0.907(0.023)$ & $1.59(0.50)$ & $1.44 / 1.46$ & $70 / 46$ \\
Burjassot & $0.030(0.012)$ & $0.939(0.021)$ & $1.18(0.29)$ & $1.43 / 1.42$ & $59 / 51$ \\
Messina & $0.037(0.025)$ & $0.933(0.031)$ & $1.20(0.39)$ & $1.42 / 1.43$ & $62 / 58$ \\
Athens-NOA & $0.043(0.007)$ & $0.906(0.015)$ & $1.45(0.42)$ & $1.43 / 1.43$ & $106 / 89$ \\
Granada & $0.048(0.017)$ & $0.904(0.031)$ & $1.71(0.51)$ & $1.43 / 1.46$ & $63 / 37$ \\
Malaga & $0.048(0.015)$ & $0.898(0.028)$ & $1.61(0.42)$ & $1.43 / 1.46$ & $65 / 41$ \\
Erdemli & $0.040(0.025)$ & $0.922(0.048)$ & $1.18(0.43)$ & $1.41 / 1.42$ & $73 / 59$ \\
Blida & $0.055(0.020)$ & $0.896(0.031)$ & $1.80(0.42)$ & $1.43 / 1.46$ & $79 / 46$ \\
Lampedusa & $0.037(0.019)$ & $0.929(0.030)$ & $2.13(0.65)$ & $1.46 / 1.48$ & $35 / 18$ \\
Forth Crete & $0.038(0.022)$ & $0.928(0.019)$ & $1.68(0.45)$ & $1.43 / 1.45$ & $49 / 33$ \\
Nes Ziona & $0.052(0.036)$ & $0.902(0.071)$ & $1.45(0.56)$ & $1.44 / 1.44$ & $97 / 58$ \\
\hline
\end{tabular}

It follows that an AAE of 1.0 corresponds to $\lambda^{-1}$ dependence of absorption. Due to its relatively constant refractive index, the absorption spectrum of fossil fuel Black Carbon (BC) aerosols emitted from incomplete combustion processes is expected to exhibit AAE of about 1.0 (Sun et al., 2007). Laboratory studies and field measurements taken in urban areas support this statement (e.g., Bond and Bergstrom, 2006; Sciare et al., 2011). Following the BC nomenclature, Brown Carbon $(\mathrm{BrC})$ is a recently introduced term for a class of light-absorbing carbonaceous material, which, unlike BC, has an imaginary part of its refractive index that increases toward shorter visible and ultraviolet (UV) wavelengths, resulting in an AAE much larger than unity (Moosmüller et al., 2009). As described by Moosmüller et al. (2009), BrC is part of Organic Carbon (OC), with OC aerosols having previously been assumed to absorb only weakly in the visible spectral region. Recent studies have suggested that the optical properties of $\mathrm{BrC}$ may be due to water-soluble organic carbon (WSOC) compounds and in particular, to humic-like substances (HULIS), which can have an AAE as large as 6-7 (Hoffer et al., 2006). The main sources of water-soluble BrC are biomass burning and, to a lesser extent, primary emissions from fossil fuel and secondary organic aerosols (Hecobian et al., 2010). In parallel, the presence of OC in biomass burning plumes has been confirmed by OMI satellite observations (Jethva and Torres, 2011).
In addition to the chemical composition of aerosols, Gyawali et al. (2009) have shown recently that the AAE of BC cores (with diameter $>10 \mathrm{~nm}$ ) that are coated by scattering shells may deviate from the typically assumed AAE of 1 relationship. Lack and Cappa (2010) have shown that BC cores coated by scattering shells can produce AAE values up to 1.6. This finding clearly complicates the attribution of observed AAE larger than 1 to $\mathrm{BrC}$ vs. mixing state. It should be also remembered that AAE is highly dependent of the wavelengths used in the calculation (Russel et al., 2010; Bahadur et al., 2012).

The mean and associated standard deviations of level 2 AAE obtained over AERONET sites are reported in Table 2 (AAE presented in this study is always calculated between 440 and $880 \mathrm{~nm}$ ). Our results indicate that average AAE values obtained over the Mediterranean fall between 0.99 and 2.16. For the urban polluted sites (Lecce, Toulon, Rome, Thessaloniki, Messina, Barcelona, Burjassot and Athens), AAE is larger than 1, with a maximum of 1.5 in Rome (see Table 2). Such AAE values obtained over urban Mediterranean sites are similar to those obtained for other urban sites by Russell et al. (2010) (AAE 0.95, $1.40,1.20$, estimated between 440 and $880 \mathrm{~nm}$ for GSFC, Creteil/Paris and Mexico City, respectively). We note that AAE obtained at urban sites in the Eastern Mediterranean 

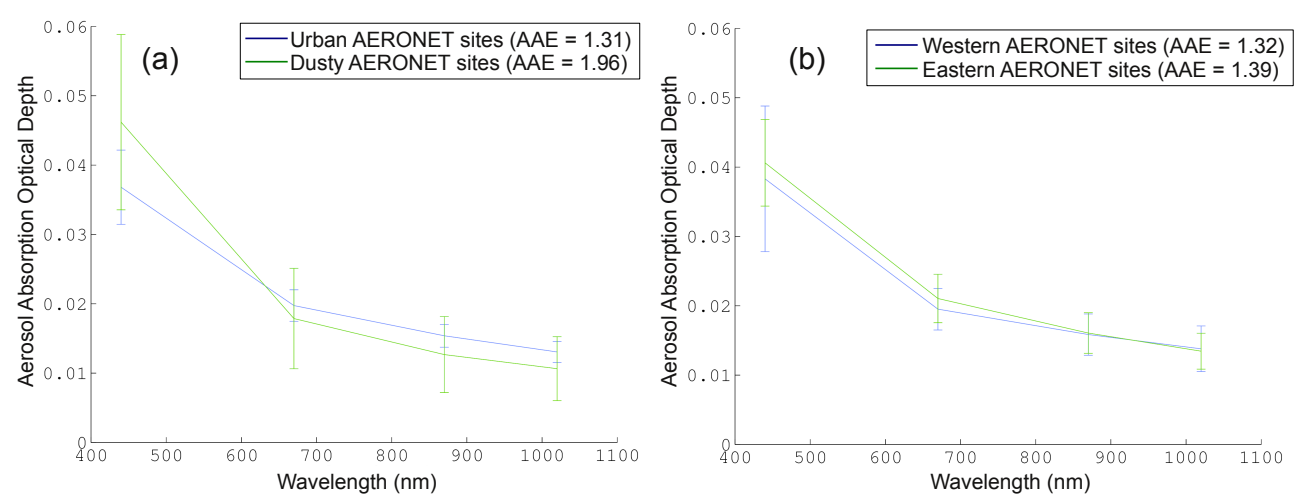

Fig. 7. Wavelength dependence of Aerosol Absorbing Optical Depth (AAOD) for Urban-Industrialised and Dusty AERONET sites (a) and for Western and Eastern AERONET sites (b). Associated standard deviations and mean AAE (calculated between 440 and $880 \mathrm{~nm}$ ) are also reported

Table 3. Adjusted parameters of particle volume size distributions averaged for the stations relevant to the western and eastern basins (see Fig. 9), assuming bimodal lognormal distributions ( $R$ is the modal radius and $\sigma_{\mathrm{g}}$ the geometric standard deviation).

\begin{tabular}{lllll}
\hline Basin & \multicolumn{2}{c}{ Western } & \multicolumn{2}{c}{ Eastern } \\
\hline Mode & Fine & Coarse & Fine & Coarse \\
Proportion $(\%)$ & 37.0 & 63.0 & 30.6 & 69.4 \\
$R(\mu \mathrm{m})$ & 0.158 & 2.34 & 0.157 & 2.23 \\
$\sigma_{\mathrm{g}}$ & 1.61 & 2.11 & 1.58 & 2.02 \\
\hline
\end{tabular}

basin are generally higher than those reported by Russell et al. (2010).

As shown in Table 2 and Fig. 7a, Mediterranean dusty sites present larger AAE $(\sim 1.96)$ compared to urban locations $(\sim 1.31)$. Lampedusa and Blida are characterized by slightly different averaged AAE (and associated standard deviation) of $2.16( \pm 0.67)$ and $1.80( \pm 0.42)$, respectively, which could be due to differences in dust size distribution. Indeed, a higher contribution of coarse dust particles near the sources (Blida) could lead to larger AAOD at $880 \mathrm{~nm}$ and decreasing AAE compared to sites far from the dust sources (Lampedusa). Mediterranean dust AAE values are found to be slightly lower than observed during the PRIDE (dust aerosols) or ACE-Asia (mixed dust-urban-industrial particles) experiments (AAE $\sim 2.34$ and 2.27, respectively). However, Mediterranean dust AAE values are similar to those observed over Bahrain/Persian Gulf (2.10, calculated between 440 and $870 \mathrm{~nm}$ ) and Arabia (1.80, between 440 and $870 \mathrm{~nm}$ ). Finally, dust AAE obtained over the Mediterranean are found to be consistent with AAE observed over Western Africa at Banizoumbou (1.7 \pm 0.6 , estimated between 440 and $870 \mathrm{~nm})$, Dakar $(1.9 \pm 0.6)$ and Ougadougou $(1.6 \pm 0.5)$ as reported by Giles et al. (2012).

One important result concerns the AAE regional gradient which appears over the Mediterranean. Analysis of
AERONET level 2 data (excluding AERONET sites affected by the presence of dust, such as Blida and Lampedusa) display lower mean AAE values over the Western basin (Table 2 and Fig. 7b). Calculated AAE over Spain (including Burjassot, Granada and Barcelona) and France (Toulon, Villefranche sur Mer and Ersa) are between 0.99 and 1.22 (Table 2) and clearly increase over Italy (AAE of 1.30-1.50), Greece (Thessaloniki and Athens) and Crete Island, with AAE values comprised between 1.30 and 1.70. Average AAE for Eastern and Western AERONET sites are about 1.39 and 1.33 , respectively (Fig. 7b). This AAE regional gradient indicates that mineral dust and/or organic absorbing particles might make a larger contribution to the total aerosol load over the Eastern Mediterranean. As the AERONET level-2 product retains only high-quality cases having AOD higher than 0.4 at $440 \mathrm{~nm}$ for estimating AAOD, this gradient supports a larger influence of mineral dust over the Eastern region. Figure 8 plots the particle size distribution retrieved from level2 AERONET sky measurements (Dubovik et al., 2000) and averaged over the eastern and western stations. Larger concentrations are generally found in the eastern basin, but the difference appears only significant for the coarse mode. If we fit those distributions by a bimodal lognormal distribution, the coarse mode is found to have a slightly larger relative contribution in the eastern basin (Table 3). In addition, Fig. 9 reports AAE for northern and southern AERONET sites classified for the western (Fig. 9a) and eastern (Fig. 9b) basins. In this case, the regional latitudinal gradient is clearly more pronounced over the western basin, where the mean AAE is about 1.77 and 1.22 for the northern and southern AERONET sites, respectively, due to the desert dust influence. This gradient is also well observed over the eastern basin with a moderate difference in AAE between the Southern (mean AAE of 1.47) and Northern (mean AAE of 1.34) AERONET sites, respectively. 


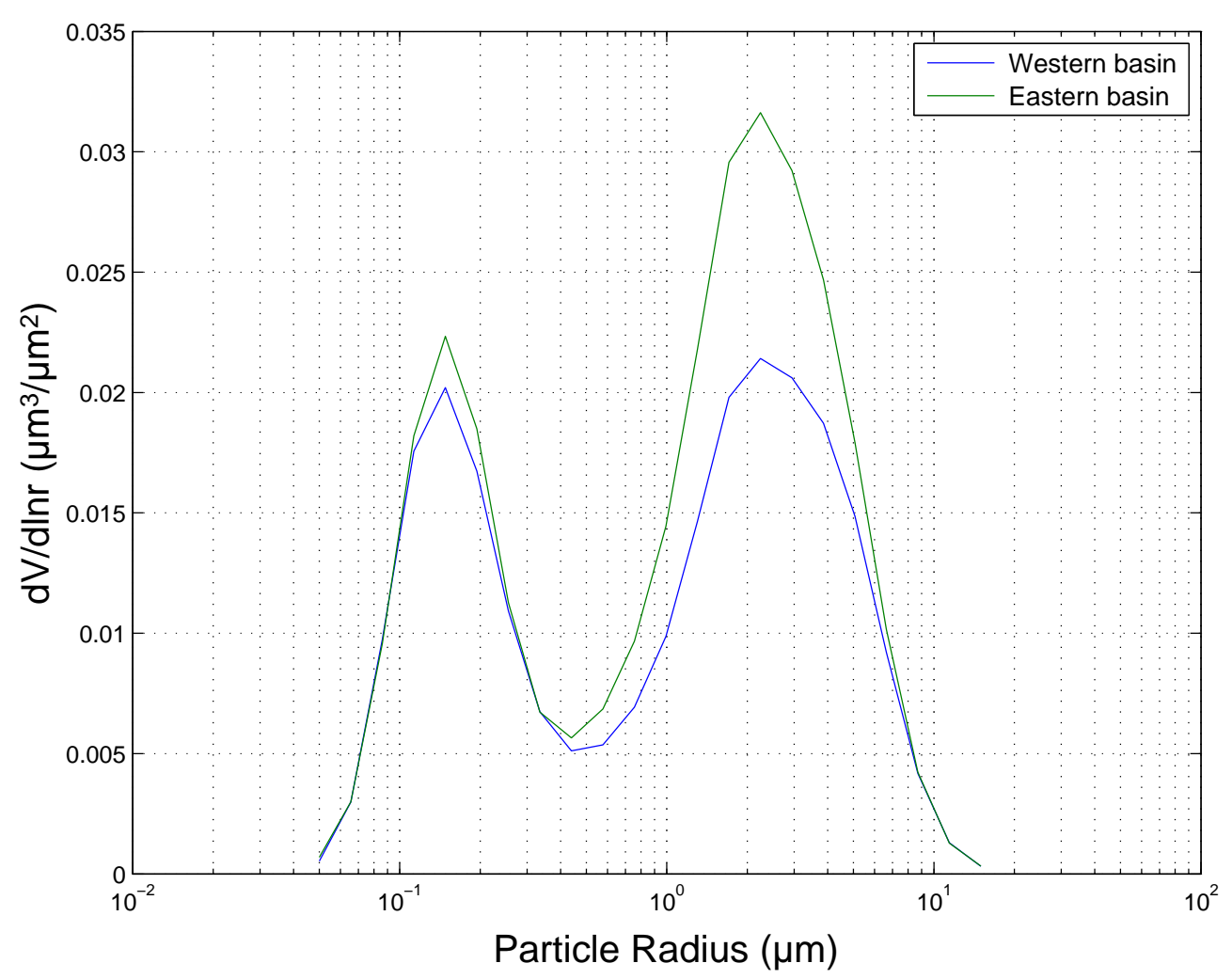

Fig. 8. AERONET level-2 aerosol volume size distribution averaged over the 8 eastern and 14 western sites (see Table 1). Inversion is performed in 22 logarithmically equidistant size bins between 0.05 and $15 \mu \mathrm{m}$ in radius. Adjusted parameters are given in Table 3 .
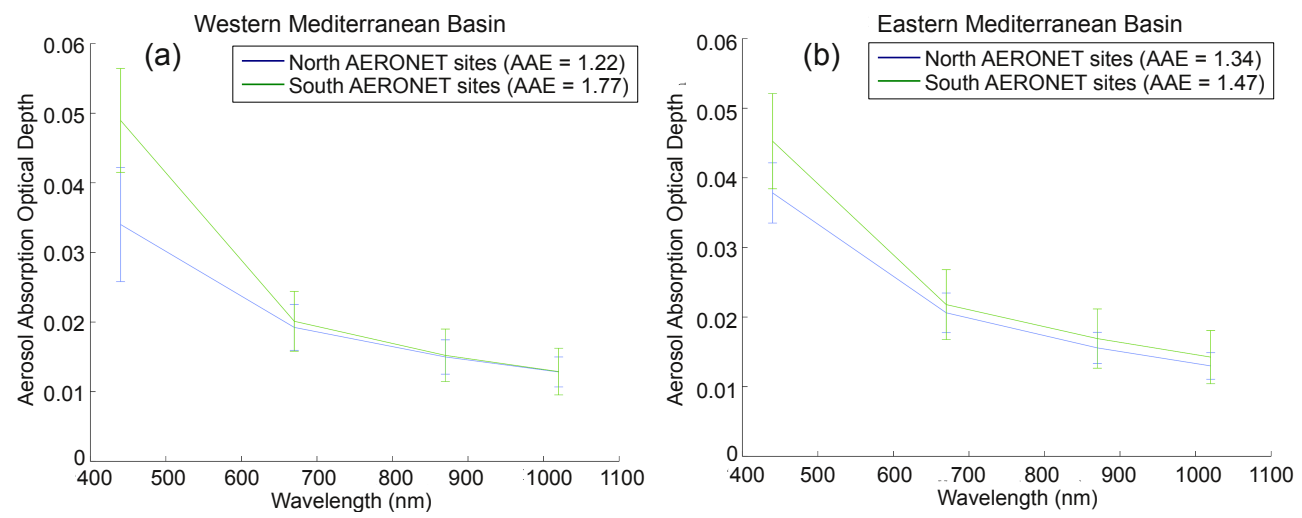

Fig. 9. Wavelength dependence of Aerosol Absorbing Optical Depth (AAOD) for Northern and Southern AERONET sites classified over the (a) Western and (b) Eastern basins. Associated standard deviations and mean AAE (calculated between 440 and $880 \mathrm{~nm}$ ) are also reported

\subsubsection{Aerosol level-1.5 product}

As mentioned below, AERONET data quality criteria do not support the study of the brown carbon influence on absorbing properties in most cases, as smoke plumes are generally characterized by moderate AOD $(0.2<$ AOD $<0.5)$. Furthermore, most AERONET sites do not provide observations in near UV where the influence of brown carbon is more prevalent. However and as already mentioned, smoke aerosols that contain high concentrations of organics are characterized by large AAE (for SAFARI African biomass smoke, AAE 1.45, calculated between 325 and $1000 \mathrm{~nm}$; Russell et al., 2010). In addition, the work of Kirchstetter et al. (2004) and Jethva and Torres (2011) confirm the high AAE values of smoke aerosols when taking into account wavelengths shorter than $440 \mathrm{~nm}$.

In order to investigate the possible role of smoke aerosols, we have conducted complementary analyses using 

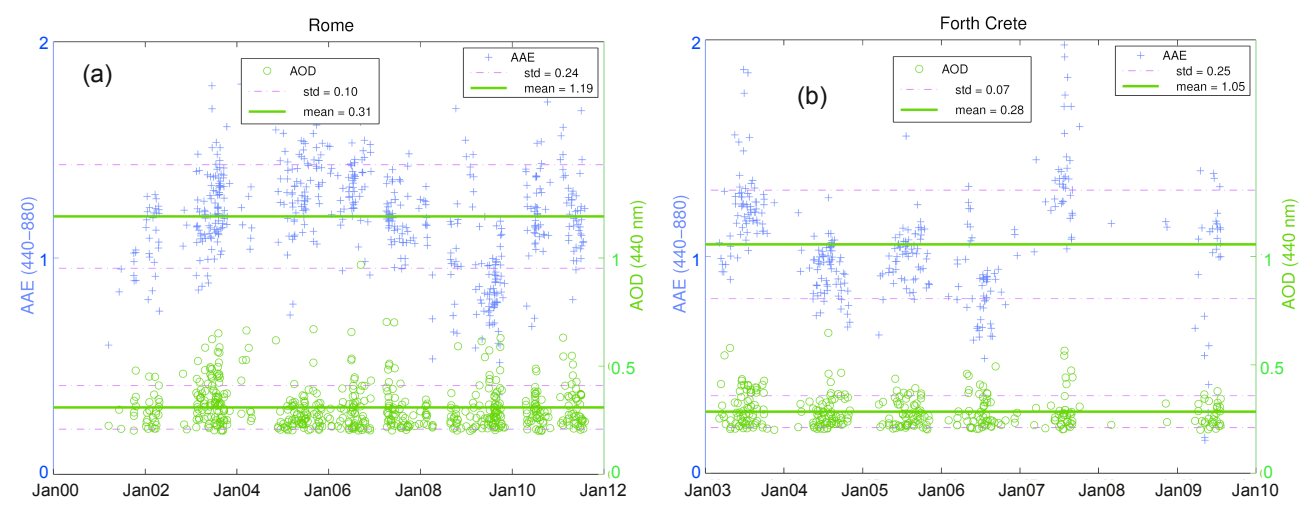

Fig. 10. AAE (calculated between 440 and $870 \mathrm{~nm}$ ) and AOD $(440 \mathrm{~nm})$ estimated from AERONET Level 1.5 data for Rome (a) and Crete (b) AERONET sites. Mean values and standard deviations are included.

AERONET level-1.5 retrievals with data screened for Angström Exponent $>1.0$ to avoid mineral dust aerosols (level 2 data are not used here for keeping consistency). For these data (AOD > 0.2 and $\mathrm{AE}>1.0$ ), AAOD uncertainties are about 0.01 (O. Dubovik, personal communication). Results of calculations are shown in Fig. 10 for two different AERONET sites: Crete and Rome (Barcelona and Lecce are provided in annexe material), demonstrating that AAE values larger than 1 are derived in a number of cases. Over Rome, we observe AAE values reaching 1.6-1.7 in number of cases (mean of 1.19), suggesting that organic particles could affect shortwave absorption over this site. Similar conclusions are obtained in Lecce and Athens (not shown), with average AAE of 1.15. In Lecce, AAE values larger than 1 are observed in all years from 2003 to 2011 with maxima during summer (not shown), indicating that a significant fraction of the aerosol absorption in Southern Italy is due to $\mathrm{BrC}$. However, the Forth Crete site is characterized by lower mean AAE (1.05) even though values up to 1.7 were derived during summer 2003 intense heat wave event. These higher values are consistent with a large agriculture waste biomass burning smoke contribution originating from the region surrounding the Black Sea and transported over Crete (Sciare et al., 2003, 2008). This influence of wood burning shows a maximum during summertime, consistent with the maxima in AAOD observed in that season over Moldova and Northern Greece, which are on the path of air masses originating from the Black Sea region and transported over the Eastern Mediterranean. Finally, over Barcelona, even if the mean value is near unity, indicating that $\mathrm{BC}$ aerosol is the main contributor to absorption, a large range of AAE is also observed, with maxima around 1.6. In such a case, organic particles could participate to the absorption of solar radiation as suggested by Shinozuka et al. (2009) during the MILAGRO experiment. Further analysis is needed to link the calculated AAE with the chemical composition of aerosols over different AERONET sites when such data are available. To conclude, such additional analysis of AERONET level-1.5 data reveal that, in addition to dust particles, organic aerosols also contribute to shortwave absorption over the Mediterranean. This result demonstrates that current regional climate models treating $\mathrm{OC}$ as nonabsorbing over Mediterranean underestimate the total warming effect of carbonaceous particles by neglecting part of atmospheric heating.

\subsection{Aerosol Single Scattering Albedo (SSA)}

\subsubsection{AERONET Level 2 observations}

As mentioned previously, SSA (level-2) has been determined from AERONET inversions at different wavelengths. Longterm SSA observations (more than $5 \mathrm{yr}$, i.e., Modena and Rome) display average daily values between $0.70 \pm 0.04$ and $0.97 \pm 0.04(440 \mathrm{~nm})$ with no significant trends. Over urban sites, Table 2 indicates that in most cases Mediterranean urban-industrial polluted locations appear as "moderately" absorbing with SSA close to $\sim 0.95 \pm 0.04$ (at $440 \mathrm{~nm}$ ). Such SSA values are found to be in the same range as AERONET SSA observed in Creteil (a suburb of Paris) $\sim 0.94 \pm 0.04$ (at $440 \mathrm{~nm}$, yearly mean of 1999) and lower than SSA obtained at GFSC (Goddard Space Flight Center Greenbelt, Maryland) $(0.98 \pm 0.04$ at $440 \mathrm{~nm}$, mean value for the 1993 to 2000 period) (Dubovik et al., 2002). Over the Mediterranean, the highest urban-industrial aerosol absorption is observed for Rome (SSA of 0.89) and Athens (0.90) in accordance with AAOD observations. It should be noted that such values are in the same range as the one derived in Mexico (SSA $\sim 0.90$ at $440 \mathrm{~nm}$, mean value for the 1999 to 2000 period; Dubovik et al., 2002).

Even if not directly comparable with in-situ SSA observations due to differences in temporal sampling and vertical integration, we attempted to compare AERONET SSA with in-situ estimates for urban/industrial Mediterranean zones. Over Southern France, AERONET SSA is comparable to insitu observations published by Saha et al. (2008) and Mallet et al. $(2003,2004)$, with SSA of 0.85 (here at $550 \mathrm{~nm}$ ) for the period 2005-2006 and during the summer 2001, 

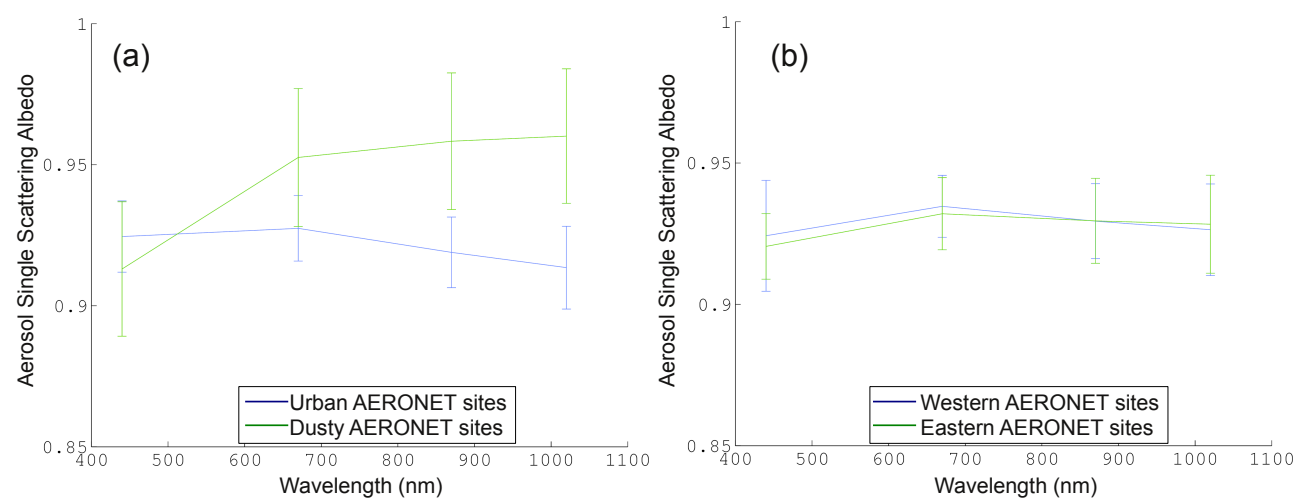

Fig. 11. Wavelength dependence of Single Scattering Albedo (SSA) for Urban and Dusty AERONET sites (a) and for Western and Eastern AERONET sites (b). Standard deviations are also reported.

respectively. Similar concurrence is observed with SSA aircraft measurements obtained by Mallet et al. (2005) over the Marseille/Etang de Berre area (SSA $\sim 0.88-0.93$ at $550 \mathrm{~nm}$ during summer 2001).

Over Southern Spain, AERONET SSA (Burjassot and Granada) display mean values of $0.93 \pm 0.04$ and $0.90 \pm 0.04$ (at $440 \mathrm{~nm}$ ), consistent with the values reported by Horvarth et al. (2002) at Almeria (SSA of 0.86-0.90) during June 1999. Over Greece, the differences between AERONET $(0.91 \pm 0.04$ at Athens and $0.94 \pm 0.04$ at Thessaloniki) and in-situ observations (0.82 in Thessaloniki, Chazette and Liousse, 2001) obtained for two polluted events of June 1997 are more pronounced. Over southeastern Italy, Tafuro et al. (2007) reported a value of $\sim 0.94$ during summer (20032004 years) for anthropogenic particles, consistent with Lecce and Messina AERONET measurements $(0.92 \pm 0.04$ and $0.94 \pm 0.04$ ).

For "dusty" sites, average SSA is in the range of 0.90 $0.92 \pm 0.04$ at $440 \mathrm{~nm}$ (see Table 2) indicating that dust particles are moderately absorbing over the Mediterranean. For this aerosol type, comparisons between AERONET SSA and in-situ observations are more limited, as most of estimates were obtained with remote-sensing techniques (Di Biagio et al., 2009; Meloni et al., 2004, 2007). In contrast to such "moderate" dust SSAs, several studies reported larger absorbing efficiencies over the Mediterranean. Di Biagio et al. (2009) indicated that SSA (at $415.6 \mathrm{~nm}$ ) for desert dust showed large variability, between 0.7 and 0.9 during the 2004 to 2007 period. Di Biagio et al. (2009) determined that $57 \%$ of the dust events with SSA (at $415.6 \mathrm{~nm}$ ) lower than 0.75 correspond to trajectories (at $750 \mathrm{~m}$ ) originating from central Europe, and trajectories ending at 2000 and $4000 \mathrm{~m}$ coming from Africa. In these cases, the presence of polluted absorbing particles at lower atmospheric levels would explain the low SSA values. More recently, in the case of dust aerosols transported over Barcelona, Sicard et al. (2012) indicate surprisingly low dust SSA $(\sim 0.70$ at $440 \mathrm{~nm})$ due to the mixing of dust with smoke-polluted particles.

\subsubsection{SSA spectral dependence}

The SSA wavelength dependence obtained for urban and dusty AERONET sites is reported in Fig. 11a. We clearly note two opposite behaviors, an increase and a decrease of SSA with wavelengths, associated with dust and urban aerosol, respectively, and similar to that reported by Russell et al. (2010). Here, the SSA spectra for AERONET locations dominated by desert dust increase from $\sim 0.90-0.92 \pm 0.04$ (at $440 \mathrm{~nm}$ ) to $\sim 0.95-0.96 \pm 0.04$ (at $1020 \mathrm{~nm}$ ). In contrast, SSA is clearly decreasing for locations dominated by fine pollution aerosols, from $\sim 0.92-0.93 \pm 0.04$ (at $440 \mathrm{~nm}$ ) to $\sim 0.91-0.92 \pm 0.04$ (at $1020 \mathrm{~nm}$ ). Such a decrease seems less marked than those reported by Russell et al. (2010) for other anthropogenic sites.

Figure $11 \mathrm{~b}$ presents the average SSA spectra obtained for the western and eastern Mediterranean AERONET sites. The mean value calculated at $440 \mathrm{~nm}$ for the eastern Mediterranean sites is slightly lower $(\sim 0.92 \pm 0.04)$ than that over the western part $(\sim 0.94 \pm 0.04)$. This result is consistent with AAE observations, suggesting a more pronounced contribution of dust particles over the Eastern basin. As shown in Fig. 11b, this finding is based only on the shortest wavelengths provided by AERONET $(440 \mathrm{~nm})$. Indeed, the difference in SSA becomes negligible for longer wavelengths $(670,870$ and $1020 \mathrm{~nm}$, Fig. 11b). In that sense, new AERONET photometer retrievals at $340 \mathrm{~nm}$ should be very helpful, but unfortunately are not yet available.

\section{Conclusions}

A multi-year climatology of column-effective aerosol absorption properties obtained over the Mediterranean from AERONET ground-based remote-sensing observations is presented. The focus of this study was on characterizing Aerosol Absorption Optical Depth (AAOD) and Single Scattering Albedo (SSA), and their spectral dependence. The AAOD dataset is composed of daily averaged AERONET 
level 2 data from 22 stations mainly under the influence of urban-industrial and/or soil dust aerosols. The datasets span 1996-2012, but most data are from the 2003-2011 period. Since AERONET level-2 absorption products are limited to high aerosol load (AOD at $440 \mathrm{~nm}>0.4$ ), which are most often related to the presence of desert dust, we also considered level-1.5 AAOD data despite their higher uncertainty.

Daily averaged AAOD values obtained from sunphotometer observations over the Mediterranean at $440 \mathrm{~nm}$ ranged from $0.024 \pm 0.010$ to $0.050 \pm 0.010$ for urban sites (with maxima observed over Rome), whereas for dusty sites, AAOD varied from $0.040 \pm 0.010$ to $0.055 \pm 0.010$. The analysis of the corresponding SSA values showed that aerosol over Mediterranean urban-industrial locations appeared "moderately" absorbing, with SSA at $440 \mathrm{~nm}$ close to $\sim 0.94-0.95 \pm 0.04$, although in some locations (Rome and Athens) the aerosol was as absorbing as heavily polluted sites such as Mexico City.

The spectral dependence of absorbing properties was also studied, using the Absorbing Angström Exponent (AAE) estimated between 440 and $870 \mathrm{~nm}$. For most Mediterranean sites, AAE is larger than 1, indicating strong shortwave absorption that can be associated with the presence of Brown Carbon (BrC) and/or mineral dust (having high iron content) aerosols. Sun-photometer level-2 data analysis indicates a possible AAE regional gradient, with higher values obtained over the eastern basin $\left(\mathrm{AAE}_{\mathrm{East}}=1.39 / \mathrm{AAE}_{\mathrm{West}}=1.33\right)$. In parallel, the North-South AAE gradient is more pronounced, especially over the western basin, with $\mathrm{AAE}_{\mathrm{North}}$ and $\mathrm{AAE}_{\text {South }}$ of about 1.22 and 1.77 , respectively.

The complementary analysis using level-1.5 AERONET retrievals with data screened to avoid mineral dust aerosols (i.e., AOD > 0.2 and Angström Exponent > 1.0) show that some Mediterranean sites are affected by organic absorbing aerosols (mean AAE 1.15), especially Rome, Lecce, Burjassot and Athens. The effect is found to be lower for the Barcelona and Forth Crete AERONET sites (mean AAE of about 1.0). This result highlights that current regional climate models that treat $\mathrm{OC}$ as purely scattering over the Mediterranean underestimate the total warming effect of carbonaceous aerosols and neglect part of the atmospheric heating due to particles.

Acknowledgements. This work was undertaken is the framework of the MISTRALS/ChArMEx program. We acknowledge the AERONET and PHOTONS sun-photometer networks and the PIs of the 22 selected stations and their staff for their work to produce the dataset used in this study. This research has received funding from the French National Research Agency (ANR) project ADRIMED (contract ANR-11-BS56-0006).
Edited by: T. Wagner

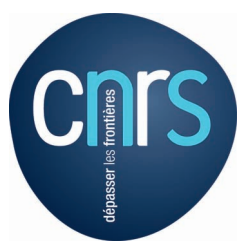

The publication of this article is financed by CNRS-INSU.

\section{References}

Antoine, D. and Nobileau, D.: Recent increase of Saharan dust transport over the Mediterranean Sea, as revealed from ocean color satellite (SeaWiFS) observations, J. Geophys. Res., 111, D12214, doi:10.1029/2005JD006795, 2006.

Bahadur, R., Praveen, P. S., Yangyang X., and Ramanathan, V.: Solar absorption by elemental and brown carbon determined from spectral observations, P. Natl. Acad. Sci. USA, 109, 1736617371, doi:10.1073/pnas.1205910109, 2012.

Barnaba, F. and Gobbi, G. P.: Aerosol seasonal variability over the Mediterranean region and relative impact of maritime, continental and Saharan dust particles over the basin from MODIS data in the year 2001, Atmos. Chem. Phys., 4, 2367-2391, doi:10.5194/acp-4-2367-2004, 2004.

Bond, T. C. and Bergstrom, R. W.: Light absorption by carbonaceous particles: an investigative review, Aerosol Sci. Technol., 40, 27-47, 2006.

Chazette, P. and Liousse, C.: A case study of optical and chemical ground apportionment for urban aerosols in Thessaloniki, Atmos. Environ., 35, 2497-2506, 2001.

Di Biagio, C., di Sarra, A., Meloni, D., Monteleone, F., Piacentino, S., and Sferlazzo, D.: Measurements of Mediterranean aerosol radiative forcing and influence of the single scattering albedo, J. Geophys. Res., 114, D06211, doi:10.1029/2008JD011037, 2009.

Dubovik, O. and King, M. D.: A flexible inversion algorithm for retrieval of aerosol optical properties from Sun and sky radiance measurements, J. Geophys. Res., 105, 20673-20696, 2000.

Dubovik, O., Holben, B. N., Eck, T. F., Smirnov, A., Kaufman, Y. J., King, M. D., Tanré, D., and Slutsker, I.: Variability of absorption and optical properties of key aerosol types observed in worldwide locations, J. Atmos. Sci., 59, 590-608, 2002.

Dubovik, O., Sinyuk, A., Lapyonok, T., Holben, B. N., Mishchenko, M., Yang, P., Eck, T. F., Volten, H., Muñoz, O., Veihelmann, B., van der Zande, W. J., Leon, J.-F., Sorokin, M., and Slutsker, I.: Application of spheroid models to account for aerosol particle nonsphericity in remote sensing of desert dust, J. Geophys. Res., 111, D11208, doi:10.1029/2005JD006619, 2006.

Dubovik, O., Herman, M., Holdak, A., Lapyonok, T., Tanré, D., Deuzé, J. L., Ducos, F., Sinyuk, A., and Lopatin, A.: Statistically optimized inversion algorithm for enhanced retrieval of aerosol properties from spectral multi-angle polarimetric satellite observations, Atmos. Meas. Tech., 4, 975-1018, doi:10.5194/amt-4975-2011, 2011.

Foltz, G. R. and McPhaden, M. J.: Impact of Saharan dust on tropical North Atlantic SST, J. Climate, 21, 5048-5060, 2008.

Formenti, P., Boucher, O., Reiner, T., Sprung, D., Andreae, M.O., Wendisch, M., Wex, H., Kindred, D. Dewey, K., J.Kent, J., Tzortziou, M., Vasaras, A., and Zerefos, C.: STAAARTE-MED 1998 summer airborne measurements over the Aegean Sea, 1. 
Aerosol particles and trace gases, J. Geophys. Res., 107, 4450, doi:10.1029/2001JD001337, 2002a.

Formenti, P., Boucher, O., Reiner, T., Sprung, D., Andreae, M.O., Wendisch, M., Wex, H., Kindred, D., Tzortziou, M., Vasaras, A., and Zerefos, C.: STAAARTE-MED 1998 summer airborne measurements over the Aegean Sea, 2. Aerosol scattering and absorption, and radiative calculations, J. Geophys. Res., 107, 4451, doi:10.1029/2001JD001536, 2002b.

Fotiadi, A., Hatzianastassiou, N., Drakakis, E., Matsoukas, C., Pavlakis, K.G., Hatzidimitriou, D., Gerasopoulos, E., Mihalopoulos, N., and Vardavas I.: Aerosol physical and optical properties in the Eastern Mediterranean Basin, Crete, from Aerosol Robotic Network data, Atmos. Chem. Phys., 6, 53995413, 2006,

http://www.atmos-chem-phys.net/6/5399/2006/.

Gerasopoulos, E., Andreae, M. O., Zerefos, C. S., Andreae, T. W., Balis, D., Formenti, P., Merlet, P., Amiridis, V., and Papastefanou, C.: Climatological aspects of aerosol optical properties in Northern Greece, Atmos. Chem. Phys., 3, 2025-2041, doi:10.5194/acp-3-2025-2003, 2003.

Giles, D. M., Holben, B. N., Eck, T. F., Sinyuk, A., Smirnov, A., Slutsker, I., Dickerson, R. R., Thompson, A. M., and Schafer, J. S.: An analysis of AERONET aerosol absorption properties and classifications representative of aerosol source regions, J. of Geophys. Res., 117, D17203, doi:10.1029/2012JD018127, 2012.

Giorgi, F.: Climate change hot-spots, Geophys. Res. Lett., 33, L08707, doi:10.1029/2006GL025734, 2006.

Giorgi, F. and Lionello, P.: Climate change projections for the Mediterranean region, Global Planet. Change, 63, 90-104, 2008.

Gyawali, M., Arnott, W. P., Lewis, K., and Moosmüller, H.: In situ aerosol optics in Reno, NV, USA during and after the summer 2008 California wildfires and the influence of absorbing and non-absorbing organic coatings on spectral light absorption, Atmos. Chem. Phys., 9, 8007-8015, doi:10.5194/acp-9-8007-2009, 2009.

Hatzianastassiou, N., Gkikas, A., Mihalopoulos, N., Torres, O., and Katsoulis, B. D.: Natural versus anthropogenic aerosols in the eastern Mediterranean basin derived from multiyear TOMS and MODIS satellite data, J. Geophys. Res., 114, D24202, doi:10.1029/2009JD011982, 2009.

Hecobian, A., Zhang, X., Zheng, M., Frank, N., Edgerton, E. S., and Weber, R. J.: Water-Soluble Organic Aerosol material and the light-absorption characteristics of aqueous extracts measured over the Southeastern United States, Atmos. Chem. Phys., 10, 5965-5977, doi:10.5194/acp-10-5965-2010, 2010.

Holben, B. N., Eck, T. F., Slutsker, I., Tanré, D., Buis, J. P., Setzer, A., Vermote, E. F., Reagan, J. A., Kaufman, Y. J., Nakajima, T., Lavenu, F., Jankowiak, I., and Smirnov, A.: AERONET - A federated instrument network and data archive for aerosol characterization, Remote Sens. Environ., 66, 1-16, 1998.

Holben, B. N., Eck, T. F., Slutsker, I., Smirnov, A., Sinyuk, A., Schafer, J., Giles, D., and Dubovik, O.: AERONET's Version 2.0 Quality Assurance Criteria, In Remote Sensing of the Atmosphere and Clouds, edited by: Tsay, S. C. et al., Proc. SPIE, 6408, 64080Q, doi:10.1117/12.706524, 2006.

Hoffer, A., Gelencsér, A., Guyon, P., Kiss, G., Schmid, O., Frank, G. P., Artaxo, P., and Andreae, M. O.: Optical properties of humic-like substances (HULIS) in biomass-burning aerosols, At- mos. Chem. Phys., 6, 3563-3570, doi:10.5194/acp-6-3563-2006, 2006.

Horvath, H., Alados Arboledas, L., Olmo, F. J., Jovanovic, O., Gangl, M., Sanchez, C., Sauerzopf, H., and Seidl, S.: Optical characteristics of the aerosol in Spain and Austria and its effect on radiative forcing, J. Geophys. Res., 107, 4386, doi:10.1029/2001JD001472, 2002.

Jethva, H. and Torres, O.: Satellite-based evidence of wavelengthdependent aerosol absorption in biomass burning smoke inferred from Ozone Monitoring Instrument, Atmos. Chem. Phys., 11, 10541-10551, doi:10.5194/acp-11-10541-2011, 2011.

Kirchstetter, T. W., Novakov, T., and Hobbs, P. V.: Evidence that the spectral dependence of light absorption by aerosols is affected by organic carbon, J. Geophys. Res., 109, D21208, doi:10.1029/2004JD004999, 2004.

Kubilay, N., Cokacar, T., and Oguz, T.: Optical properties of mineral dust outbreaks over the northeastern Mediterranean, J. Geophys. Res., 108, 4666, doi:10.1029/2003JD003798, 2003.

Lack, D. A. and Cappa, C. D.: Impact of brown and clear carbon on light absorption enhancement, single scatter albedo and absorption wavelength dependence of black carbon, Atmos. Chem. Phys., 10, 4207-4220, doi:10.5194/acp-10-4207-2010, 2010.

Lau, K. M., Kim, K. M., Sud, Y. C., and Walker, G. K.: A GCM study of the response of the atmospheric water cycle of West Africa and the Atlantic to Saharan dust radiative forcing, Ann. Geophys., 27, 4023-4037, doi:10.5194/angeo-27-40232009, 2009.

Lionello, P., Abrantes, F., Congedi, L., Dulac, F., Gacic, M., Gomiz, D., Goodess, C., Hoff, H., Kutiel, H., Luterbacher, J., Planton, S., Reale, M., Schroeder, K., Struglia, M. V., Toretti, A., Tsimplis, M., Xoplaki, E., Ulbrich, U., and Xoplaki, E. : Mediterranean climate: Background information. In The Climate of the Mediterranean Region: From the Past to the Future, P. Lionello Ed., Elsevier, 590 pp., 2012.

Mallet, M., Roger, J. C., Despiau, S., Dubovik, O., and Putaud, J. P.: Microphysical and optical properties of aerosol particles in urban zone during ESCOMPTE, Atmos. Res., 69, 73-97, 2003.

Mallet, M., Roger, J. C., Despiau, S., Putaud, J. P., and Dubovik, O.: A study of the mixing state of black carbon in urban zone, J. Geophys. Res., 109, D04202, doi:10.1029/2003JD003940, 2004.

Mallet, M., Van Dingenen, R., Roger, J. C., Despiau, S., and Cachier, H.: In situ airborne measurements of aerosol optical properties during photochemical pollution events, J. Geophys. Res., 110, D03205, doi:10.1029/2004JD005139, 2005.

Mallet, M., Pont, V., Liousse, C., Roger, J. C., and Dubuisson, P.: Simulation of aerosol radiative properties with the ORISAMRAD model during a pollution event (ESCOMPTE 2001), Atmos. Environ., 40, 7696-7705, 2006.

Mallet, M., Tulet, P., Serça, D., Solmon, F., Dubovik, O., Pelon, J., Pont, V., and Thouron, O.: Impact of dust aerosols on the radiative budget, surface heat fluxes, heating rate profiles and convective activity over West Africa during March 2006, Atmos. Chem. Phys., 9, 7143-7160, doi:10.5194/acp-9-7143-2009, 2009.

Markowicz, K. M., Flatau, P. J., Ramana, M. V., Crutzen, P. J., and Ramanathan, V.: Absorbing mediterranean aerosols lead to a large reduction in the solar radiation at the surface, Geophys. Res. Lett., 29, 1968, doi:10.1029/2002GL015767, 2002.

Meloni, D., Di Sarra, A. Di Iorio, T., and Fiocco, G.: Direct radiative forcing of Saharan dust in the Mediterranean from measurements 
at Lampedusa Island and MISR space-borne observations, J. eophys. Res., 109, D08206, doi:10.1029/2003JD003960, 2004.

Meloni, D., di Sarra, A., Pace, G., and Monteleone, F.: Aerosol optical properties at Lampedusa (Central Mediterranean). 2. Determination of single scattering albedo at two wavelengths for different aerosol types, Atmos. Chem. Phys., 6, 715-727, doi:10.5194/acp-6-715-2006, 2006.

Meloni, D., di Sarra, A., Biavati, G., DeLuisi, J. J., Monteleone, F., Pace, G., Piacentino, S., and Sferlazzo, D. M.: Seasonal behavior of Saharan dust events at the Mediterranean island of Lampedusa in the period 1999-2005, Atmos. Environ., 41, 3041-3056, 2007.

Moosmüller, H., Chakrabarty, R. K., and Arnott, W. P.: Aerosol light absorption and its measurement: A review, J. Quant. Spectrosc. Radiat. Transf., 110, 844-878, 2009.

Moulin, C., Lambert, C. E., Dayan, U., Masson, V., Ramonet, M., Bousquet, P., Legrand, M., Balkanski, Y. J., Guelle, W., Marticorena, B., Bergametti, G., and Dulac, F.: Satellite climatology of African dust transport in the Mediterranean atmosphere, J. Geophys. Res., 103, 13137-13144, 1998.

Nabat, P., Solmon, F., Mallet, M., Kok, J. F., and Somot, S.: Dust emission size distribution impact on aerosol budget and radiative forcing over the Mediterranean region: a regional climate model approach, Atmos. Chem. Phys., 12, 10545-10567, doi:10.5194/acp-12-10545-2012, 2012.

Nabat, P., Somot, S., Mallet, M., Chiapello, I., Morcrette, J. J., Solmon, F., Szopa, S., Dulac, F., Collins, W., Ghan, S., Horowitz, L. W., Lamarque, J. F., Lee, Y. H., Naik, V., Nagashima, T., Shindell, D., and Skeie, R.: A 4-D climatology (1979-2009) of the monthly tropospheric aerosol optical depth distribution over the Mediterranean region from a comparative evaluation and blending of remote sensing and model products, Atmos. Meas. Tech., 6, 1287-1314, doi:10.5194/amt-6-1287-2013, 2013.

Pace, G., di Sarra, A., Meloni, D., Piacentino, S., and Chamard, P.: Aerosol optical properties at Lampedusa (Central Mediterranean). 1. Influence of transport and identification of different aerosol types, Atmos. Chem. Phys., 6, 697-713, doi:10.5194/acp-6-697-2006, 2006.

Papadimas, C. D., Hatzianastassiou, N., Mihalopoulos, N., Querol, $\mathrm{X}$., and Vardavas, I.: Spatial and temporal variability in aerosol properties over the Mediterranean basin based on 6year (2000-2006) MODIS data, J. Geophys. Res., 113, D11205, doi:10.1029/2007JD009189, 2008.

Papadimas, C. D., Hatzianastassiou, N., Mihalopoulos, N., Kanakidou, M., Katsoulis, B. D., and Vardavas, I.: Assessment of the MODIS Collections C005 and C004 aerosol optical depth products over the Mediterranean basin, Atmos. Chem. Phys., 9, 2987 2999, doi:10.5194/acp-9-2987-2009, 2009.

Ramanathan, V., Crutzen, P. J., Kiehl, J. T., and Rosenfeld, D.: Aerosols, Climate, and The Hydrological Cycle, Science, 294, 2119-2124, 2001a.

Ramanathan, V., Crutzen, P. J., Lelieveld, J., Mitra, A. P., Althausen, D., Anderson, J., Andreae, M. O., Cantrell, W., Cass, G., Chung, C. E., Clarke, A. D., Coakley, J. A., Collins, W. D., Conant, W. C., Dulac, F., Heintzenberg, J., Heymsfield, A. J., Holben, B., Howell, S., Hudson, J., Jayaraman, A., Kiehl, J. T., Krishnamurti, T. N., Lubin, D., MacFarquhar, G., Novakov, T., Ogren, J. A., Podgorny, I. A., Prather, K., Priestley, K., Prospero, J. M., Quinn, P. K., Rajeev, K., Rasch, P., Rupert, S., Sadourny, R., Satheesh, S. K., Shaw, G. E., Sheridan, P., and Valero, F. P. J.:
The Indian Ocean Experiment: An Integrated Assessment of the Climate Forcing and Effects of the Great Indo-Asian Haze, J. Geophys. Res. Atmos., 106, 28371-28399, 2001b.

Roger, J. C., Mallet, M., Dubuisson, P., Cachier, H., Vermote, E., Dubovik, O., and Despiau, S.: A synergetic approach for estimating the local direct aerosol forcing: Application to an urban zone during the Expérience sur Site pour Contraindre les Modèles de Pollution et de Transport d'Emission (ESCOMPTE) experiment, J. Geophys. Res., 111, D13208, doi:10.1029/2005JD006361, 2006.

Russell, P. B., Bergstrom, R. W., Shinozuka, Y., Clarke, A. D., DeCarlo, P. F., Jimenez, J. L., Livingston, J. M., Redemann, J., Dubovik, O., and Strawa, A.: Absorption Angstrom Exponent in AERONET and related data as an indicator of aerosol composition, Atmos. Chem. Phys., 10, 1155-1169, doi:10.5194/acp-101155-2010, 2010

Saha, A., Mallet, M., Dubuisson, P., Piazzola, J., and Despiau, S.: One year measurements of aerosol optical properties over an urban coastal site: effect on local direct radiative forcing, Atmos. Res., 90, 195-202, 2008.

Sanchez-Gomez, E., Somot, S., and Mariotti, A.: Future changes in the Mediterranean water budget projected by an ensemble of regional climate models, Geophys. Res. Lett., 36, L21401, doi:10.1029/2009GL040120, 2009.

Sciare, J., Cachier, H., Oikonomou, K., Ausset, P., Sarda-Estéve, R., and Mihalopoulos, N.: Characterization of carbonaceous aerosols during the MINOS campaign in Crete, July-August 2001: a multi-analytical approach, Atmos. Chem. Phys., 3, 17431757, doi:10.5194/acp-3-1743-2003, 2003.

Sciare, J., Oikonomou, K., Favez, O., Liakakou, E., Markaki, Z., Cachier, H., and Mihalopoulos, N.: Long-term measurements of carbonaceous aerosols in the Eastern Mediterranean: evidence of long-range transport of biomass burning, Atmos. Chem. Phys., 8, 5551-5563, doi:10.5194/acp-8-5551-2008, 2008.

Sciare, J., d'Argouges, O., Sarda Estève, R., Gaimoz, C., Dolgorouky, C., Bonnaire, N., Favez, O., Bonsang, B., and Gros, V.: Large contribution of water insoluble secondary organic aerosols in the region of Paris (France) during wintertime, J. Geophys. Res., 116, D22203, doi:10.1029/2011JD015756, 2011.

Shinozuka, Y., Clarke, A. D., DeCarlo, P. F., Jimenez, J. L., Dunlea, E. J., Roberts, G. C., Tomlinson, J. M., Collins, D. R., Howell, S. G., Kapustin, V. N., McNaughton, C. S., and Zhou, J.: Aerosol optical properties relevant to regional remote sensing of $\mathrm{CCN}$ activity and links to their organic mass fraction: airborne observations over Central Mexico and the US West Coast during MILAGRO/INTEX-B, Atmos. Chem. Phys., 9, 6727-6742, doi:10.5194/acp-9-6727-2009, 2009.

Smirnov, A., Holben, B. N., Eck, T. F., Dubovik, O., and Slutsker, I.: Cloudscreening and quality control algorithms for the AERONET database, Remote Sens. Environ., 73, 337-349, 2000.

Solmon, F., Mallet, M., Elguindi, N., Giorgi, F., Zakey, I., and Konaré, A.: Dust impact on sahelian precipitation gradients, mechanisms and sensitivity to absorption properties, Geophys. Res. Lett., 35, L24705, doi:10.1029/2008GL035900, 2008.

Sun, H., Biedermann, L., and Bond, T. C.: Color of brown carbon: A model for ultraviolet and visible light absorption by organic carbon aerosol, Geophys. Res. Lett., 34, L17813, doi:10.1029/2007GL029797, 2007. 
Tafuro, A. M., Kinne, S., De Tomasi, F., and Perrone, M. R.: Annual cycle of direct radiative effect over Southeast Italy and sensitivity studies, J. Geophys. Res., 112, D20202, doi:10.1029/2006JD008265, 2007.

Yue, X., Lioa, H., Wang, H. J., Li, S. L., and Tang, J. P.: Role of sea surface temperature responses in simulation of the climatic effect of mineral dust aerosol, Atmos. Cehm. Phys., 11, 60496062, doi:10.5194/acp-11-6049-2011, 2011.
Zhang, J. and Reid, J. S.: A dedacal regional and global trend analysis of the aerosol optical depth using a data-assimilation grade over-water MODIS and Level 2 MISR aerosol products, Atmos. Chem. Phys., 10, 10949-10963, doi:10.5194/acp-1010949-2010, 2010. 